\title{
In vitro Evaluation of Fungicides and Bioagents for the Management of Pearl Millet Blast Caused by Pyricularia grisea (Cooke) Sacc.
}

\author{
M. Mahesh ${ }^{1 *}$, L. Malatesha ${ }^{2}$ and P. Venkataravana ${ }^{3}$ \\ ${ }^{1}$ Department of Plant Pathology, College of Sericulture, Chintamani, UAS, \\ Bengaluru, Karnataka, India \\ ${ }^{2}$ Department of plant pathology, College of Agriculture, UAS, Raichur, \\ Karnataka - 584 104, India \\ ${ }^{3}$ College of Sericulture, Chintamani, UAS, Bengaluru, Karnataka, India \\ *Corresponding author
}

\begin{tabular}{|l|}
\hline K e y w o r d s \\
Pearl millet, Blast, \\
Pyricularia grisea, \\
$\begin{array}{l}\text { Fungicide, } \\
\text { Bioagents, }\end{array}$ \\
\hline Article Info \\
\hline $\begin{array}{l}\text { Accepted: } \\
\text { 12 May } 2019 \\
\text { Available Online: } \\
\text { 10 June } 2019\end{array}$ \\
\hline
\end{tabular}

\section{Introduction}

Pearl millet [Pennisetum glaucum (L.) R. Br.] is a staple cereal grown in India having the largest area of 7.45 m.ha distributed almost over entire country with production of 9.73 $\mathrm{mt}$ of grains and productivity of $13.05 \mathrm{q} / \mathrm{ha}$ during 2016-17 (Anonymous, 2017). The crop suffers from many fungal diseases, among which blast caused by Pyricularia grisea (Cooke) Sacc. [Teleomorph: Magnaporthe grisea (Herbert) Barr.] has emerged as serious disease affecting both forage and grain production in pearl millet (Thakur et al., 2011). The disease was first recorded in Uganda in 1933. The disease has geographic 
distribution in India, Singapore and the United States. In India, the disease was first reported in 1942 from Kanpur, Uttar Pradesh (Mehta et al., 1953). Blast has become major threat to pearl millet causing considerable yield loss (Thakur et al., 2009). Keeping this in view, the present study was conducted on in vitro evaluation of different fungicide and bioagents against $P$. grisea causing blast of pearl millet.

\section{Materials and Methods}

The experiment was conducted at Department of Plant Pathology, College of Agriculture, Raichur during 2017-18. In the present study, twelve fungicides, viz., four systemic (Tricyclazole 75\% WP, Carbendazim 50\% WP, Hexaconazole 5\% EC and Azoxystrobin $23 \% \mathrm{SC}$ ), four contact (Mancozeb $75 \% \mathrm{WP}$, Zineb 75\% WP, Chlorothalonil 75\% WP and Copper oxychloride 50\% WP) and four combi fungicides viz., Custodia (Azoxystrobin 11\% + Tebuconazole18.3\% SC), Merger (Tricyclazole 18\% + Mancozeb 62\% WP), SAAF (Carbendazim 12\% + Mancozeb 63\% WP) and Avtar (Zineb 68\% WP+ Hexaconazole 4\%) were evaluated for their efficacy against $P$. grisea under in vitro by using poisoned food technique. The systemic fungicides evaluated at $0.05,0.1$ and 0.2 per cent whereas contact and combi fungicides were evaluated at $0.1,0.2$ and 0.3 per cent concentrations. The experiment was conducted using completely randomised block design (CRBD) with three replications in each treatment. The per cent inhibition of the mycelial growth of the fungus was determined by formula given by Vincent (1947).

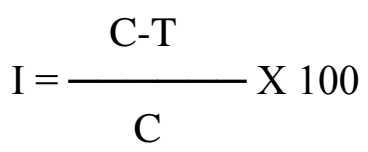

Where,
$\mathrm{I}=$ Per cent inhibition

$\mathrm{C}=$ Radial growth of fungus in control

$\mathrm{T}=$ Radial growth of fungus in treatment

Six known antagonists viz., Trichoderma viride (Tri-4), T. harzianum (Tri-5), Pseudomonas fluorescens (EP-5), $P$. fluorescens (RP-46), Bacillus subtilis (BS-16) and B. subtilis (BS-30) were evaluated for their antagonistic effect on $P$. grisea using dual culture technique as followed by Dennis and Webster, (1971). The per cent growth inhibition was recorded as described above.

\section{Results and Discussion}

\section{In vitro evaluation of systemic fungicides by using poisoned food technique}

In vitro evaluation of four systemic fungicides was carried out against $P$. grisea at $0.05,0.1$ and 0.2 per cent concentrations (Table 1 and Plate 1). Among the four systemic fungicides tested, tricyclazole was found very effective with 100 per cent mycelial inhibition at all the three concentrations, followed by carbendazim with $98.51,100$ and 100 per cent and hexaconazole inhibited 80.36, 96.29 and 100 per cent at $0.05,0.1$ and 0.2 per cent concentrations respectively, as compared to control.

However, azoxystrobin was least effective with inhibition of $11.11,22.22$ and 24.07 per cent at $0.05,0.1$ and 0.2 per cent concentrations, respectively. Irrespective of fungicidal concentrations, tricyclazole resulted cent per cent inhibition and found to be the best and significantly superior over other fungicides tested.

\section{In vitro evaluation of contact fungicides by using poisoned food technique}

The comparative efficacy of four different contact fungicides allocated at $0.1,0.2$ and 0.3 
per cent concentration. The observations on per cent growth inhibition (PGI) of mycelium recorded after seven days of incubation are showed in Table 2 and Plate 2. Results showed that, among the four contact fungicides tested, mancozeb was found highly effective with 100 per cent mycelia inhibition at all the concentrations, followed by copper oxychloride with $81.11,82.96$ and 86.66 per cent and chlorothalonil inhibited 44.44, 47.03 and 54.81per cent at 0.1, 0.2 and 0.3 per cent respectively, as compared to control. However, zineb was least effective with inhibition of $31.40,40.74$ and 44.44 per cent at $0.1,0.2$ and 0.3 per cent concentrations, respectively. Irrespective of fungicidal concentrations, mancozeb resulted cent per cent inhibition and found to be the best and significantly superior over other fungicides tested.

Table.1 In vitro evaluation of systemic fungicides against $P$. grisea causing blast of pearl millet by using poisoned food technique

\begin{tabular}{|c|l|c|c|c|c|}
\hline \multirow{2}{*}{ Sl. No. } & \multicolumn{1}{|c|}{ Fungicides } & \multicolumn{3}{|c|}{ Per cent inhibition* } & Mean \\
\cline { 3 - 6 } & & $\mathbf{0 . 0 5 \%}$ & $\mathbf{0 . 1 \%}$ & $\mathbf{0 . 2 \%}$ & \\
\hline $\mathbf{1}$ & Tricyclazole 75\% WP & $100(90.00)$ & $100(90.00)$ & $100(90.00)$ & $100(90.00)$ \\
\hline $\mathbf{2}$ & Carbendazim 50\% WP & $98.51(83.00)$ & $100(90.00)$ & $100(90.00)$ & $99.50(85.95)$ \\
\hline $\mathbf{3}$ & Hexaconazole 5\% EC & $80.36(63.70)$ & $96.29(78.9)$ & $100(90.00)$ & $92.22(73.81)$ \\
\hline $\mathbf{4}$ & Azoxystrobin 23\% SC & $11.11(19.48)$ & $22.22(28.13)$ & $24.07(29.39)$ & $19.13(25.94)$ \\
\hline $\mathbf{5}$ & Untreated control & $0.00(0.00)$ & $0.00(0.00)$ & $0.00(0.00)$ & $0.00(0.00)$ \\
\hline & & \multicolumn{2}{|c|}{ S.Em \pm} & C.D. at 1\% \\
\hline & Fungicide (A) & \multicolumn{2}{c|}{0.60} & \multicolumn{2}{c|}{2.33} \\
\hline & Concentration (B) & 0.47 & 1.80 \\
\hline Fungicide x Concentration (A x B) & \multicolumn{2}{|c|}{1.04} & 4.04 \\
\hline
\end{tabular}

Table.2 In vitro evaluation of contact fungicides against $P$. grisea causing blast of pearl millet by using poisoned food technique

\begin{tabular}{|c|c|c|c|c|c|}
\hline \multirow[t]{2}{*}{ Sl. No. } & \multirow[t]{2}{*}{ Fungicides } & \multicolumn{3}{|c|}{ Per cent inhibition* } & \multirow[t]{2}{*}{ Mean } \\
\hline & & $0.1 \%$ & $0.2 \%$ & $0.3 \%$ & \\
\hline 1 & Mancozeb 75\% WP & $100(90.00)$ & $100(90.00)$ & $100(90.00)$ & $100(90.00)$ \\
\hline 2 & Zineb $75 \% \mathrm{WP}$ & $31.40(34.09)$ & $40.74(39.67)$ & $44.44(41.81)$ & $\begin{array}{c}38.86 \\
(38.57)\end{array}$ \\
\hline 3 & Chlorothalonil 75\% WP & $44.44(41.81)$ & $47.03(43.30)$ & $54.81(47.77)$ & $\begin{array}{c}48.76 \\
(44.29)\end{array}$ \\
\hline 4 & Copper oxychloride 50\% WP & $81.11(64.24)$ & $82.96(65.62)$ & $86.66(68.58)$ & $\begin{array}{c}83.57 \\
(66.09)\end{array}$ \\
\hline 5 & Untreated control & $0.00(0.00)$ & $0.00(0.00)$ & $0.00(0.00)$ & $0.00(0.00)$ \\
\hline & & \multicolumn{2}{|c|}{ S.Em \pm} & \multicolumn{2}{|c|}{ C.D. at $1 \%$} \\
\hline & Fungicide (A) & \multicolumn{2}{|c|}{0.26} & \multicolumn{2}{|c|}{1.02} \\
\hline & Concentration (B) & \multicolumn{2}{|c|}{0.20} & \multicolumn{2}{|c|}{0.79} \\
\hline \multicolumn{2}{|c|}{ Fungicide $x$ Concentration $(\mathrm{A} \times \mathrm{B})$} & \multicolumn{2}{|c|}{0.45} & \multicolumn{2}{|c|}{1.76} \\
\hline
\end{tabular}


Table.3 In vitro evaluation of combi fungicides against $P$. grisea causing blast of pearl millet by using poisoned food technique

\begin{tabular}{|c|c|c|c|c|c|}
\hline \multirow[t]{2}{*}{ Sl. No. } & \multirow[t]{2}{*}{ Fungicides } & \multicolumn{3}{|c|}{ Per cent inhibition* } & \multirow[t]{2}{*}{ Mean } \\
\hline & & $0.1 \%$ & $0.2 \%$ & $0.3 \%$ & \\
\hline 1 & $\begin{array}{l}\text { Azoxystrobin } 11 \%+ \\
\text { Tebuconazole } 18.3 \% \text { SC } \\
\text { (Custodia) }\end{array}$ & $\begin{array}{c}79.62 \\
(63.17)\end{array}$ & $86.47(68.43)$ & $96.66(79.48)$ & $\begin{array}{c}87.58 \\
(69.37)\end{array}$ \\
\hline 2 & $\begin{array}{l}\text { Tricyclazole } 18 \%+ \\
\text { Mancozeb 62\% WP (Merger) }\end{array}$ & $\begin{array}{c}95.92 \\
(78.38)\end{array}$ & $100(90.00)$ & $100(90.00)$ & $\begin{array}{c}98.64 \\
(83.31)\end{array}$ \\
\hline 3 & $\begin{array}{l}\text { Carbendazim } 12 \%+ \\
\text { Mancozeb } 63 \% \text { WP (SAAF) }\end{array}$ & $100(90.00)$ & $100(90.00)$ & $100(90.00)$ & $100(90.00)$ \\
\hline 4 & $\begin{array}{l}\text { Zineb 68\% WP+ } \\
\text { Hexaconazole 4\% (Avtar) }\end{array}$ & $\begin{array}{c}92.22 \\
(73.81)\end{array}$ & $100(90.00)$ & $100(90.00)$ & $97.4(80.73)$ \\
\hline 5 & Untreated control & $0.00(0.00)$ & $0.00(0.00)$ & $0.00(0.00)$ & $0.00(0.00)$ \\
\hline & & \multicolumn{2}{|c|}{ S.Em \pm} & \multicolumn{2}{|c|}{ C.D. at $1 \%$} \\
\hline & Fungicide (A) & \multicolumn{2}{|c|}{0.39} & \multicolumn{2}{|c|}{1.49} \\
\hline & Concentration (B) & \multicolumn{2}{|c|}{0.30} & \multicolumn{2}{|c|}{1.16} \\
\hline \multicolumn{2}{|c|}{ Fungicide x Concentration (A x B) } & \multicolumn{2}{|c|}{0.67} & \multicolumn{2}{|c|}{2.59} \\
\hline
\end{tabular}

Table.4 In vitro antagonistic effect of different bioagents against $P$. grisea causing blast of pearl millet by using dual culture technique

\begin{tabular}{|c|l|c|c|}
\hline SI. NO. & \multicolumn{1}{|c|}{ Bio agents } & $\begin{array}{c}\text { Isolate } \\
\text { number }\end{array}$ & $\begin{array}{c}\text { Per cent mycelial } \\
\text { inhibition* }\end{array}$ \\
\hline $\mathbf{1}$ & Trichoderma viride & Tri-4 & $66.66(54.74)$ \\
\hline $\mathbf{2}$ & Trichoderma harzianum & Tri-5 & $77.03(61.37)$ \\
\hline $\mathbf{3}$ & Pseudomonas fluorescens & EP-5 & $41.84(40.31)$ \\
\hline $\mathbf{4}$ & Pseudomonas fluorescens & RP-46 & $67.77(55.41)$ \\
\hline $\mathbf{5}$ & Bacillus subtilis & BS-16 & $38.51(38.36)$ \\
\hline $\mathbf{6}$ & Bacillus subtilis & BS-30 & $44.07(41.60)$ \\
\hline $\mathbf{7}$ & Untreated control & - & $0.00(0.00)$ \\
\hline & S.Em \pm & & $\mathbf{0 . 7 4}$ \\
\hline & C.D. at $\mathbf{1 \%}$ & & $\mathbf{3 . 1 1}$ \\
\hline
\end{tabular}

*Mean of three replications

Figures in the parentheses are arcsine transformed values 


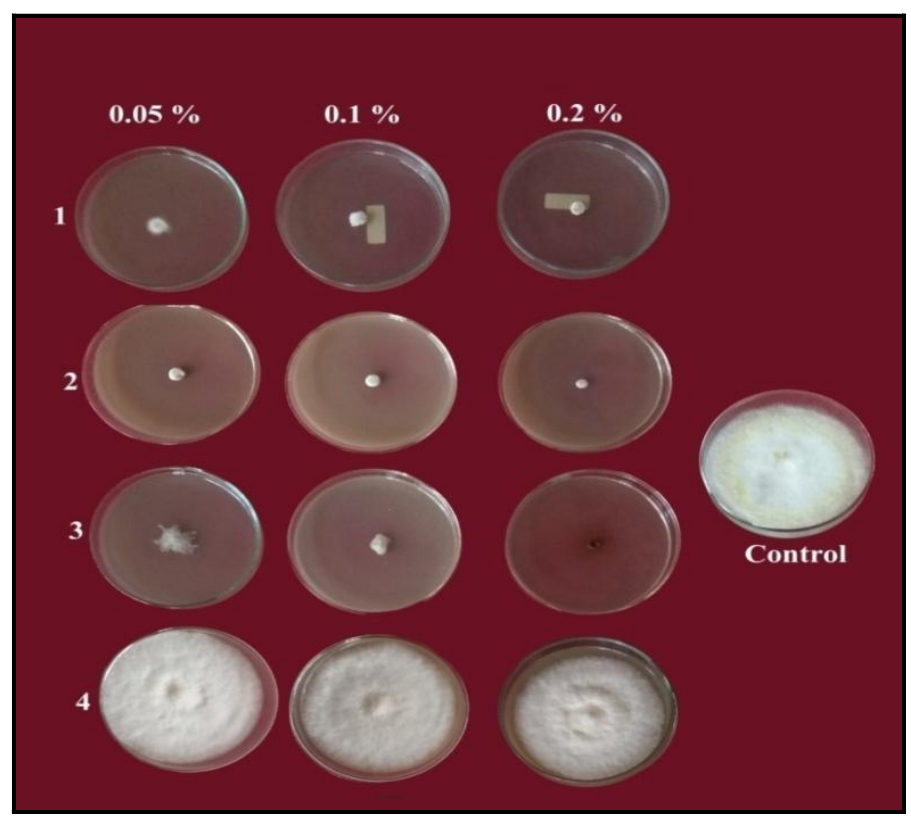

Plate 1. In vitro evaluation of systemic fungicides against $P$. grisea

Note: 1-Tricyclazole 75\% WP, 2- Carbendazim 50\% WP, 3- Hexaconazole 5\% EC and 4- Azoxystrobin 23\% SC

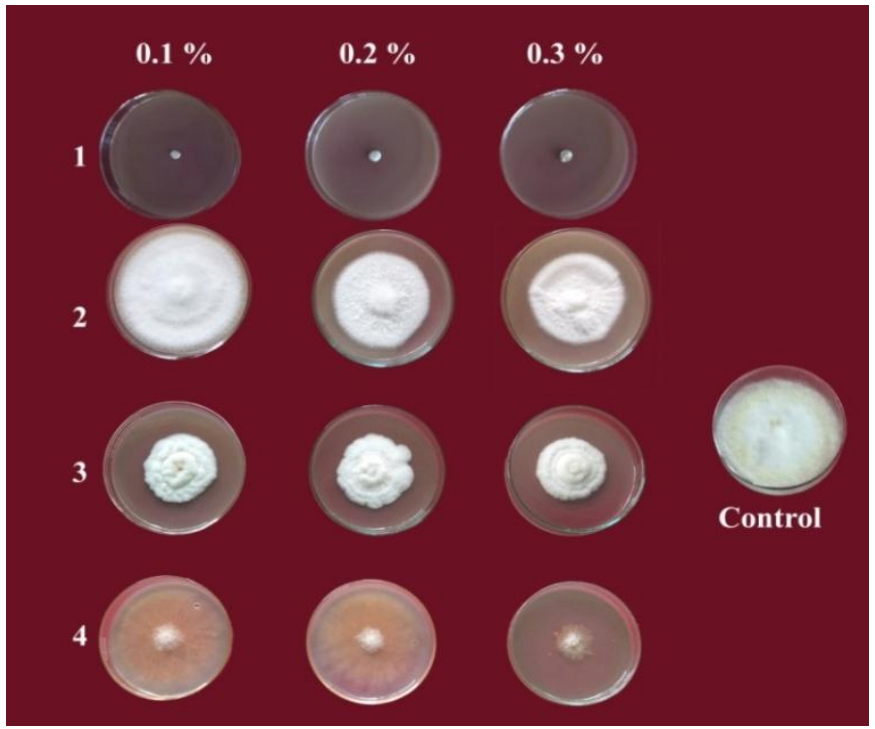

Plate 2. In vitro evaluation of contact fungicides against $P$. grisea

Note: 1- Mancozeb 75\% WP, 2- Zineb 75\% WP, 3- Chlorothalonil 75\% WP and 4- Copper oxychloride 50\% WP 


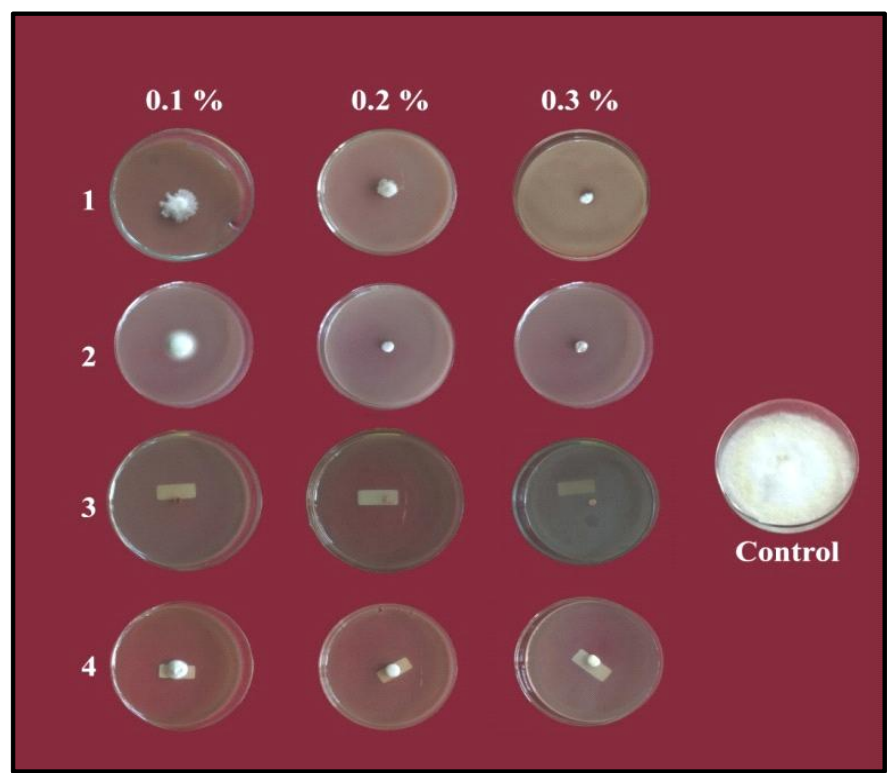

Plate 3. In vitro evaluation of combi fungicides against $P$. grisea

Note: 1- Azoxystrobin 11\% + Tebuconazole18.3\% SC, 2- Tricyclazole $18 \%+$ Mancozeb 62\% WP, 3- Carbendazim 12\% + Mancozeb 63\% WP and 4Zineb 68\% WP+ Hexaconazole 4\%

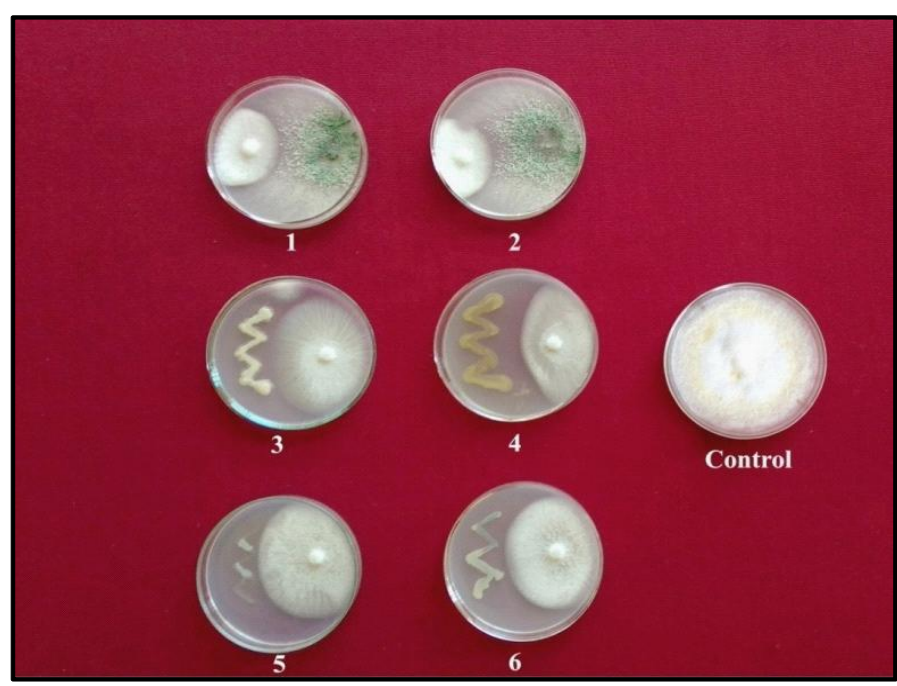

Plate 4. In vitro evaluation of bioagents against $P$. grisea by dual culture technique

Note: 1- Trichoderma viride (Tri-4),, 2- Trichoderma harzianum (Tri-5), 3- Pseudomonas fluorescens (EP-5), 4- Pseudomonas fluorescens (Rp64) 5-Bacillus subtilis (Bs-16) and 6-Bacillus subtilis (Bs-30) 
In vitro evaluation of combi fungicides by using poisoned food technique

Four combination molecules (fungicides) were evaluated to know their efficiency against $P$. grisea through poison food techniques (Table 3 and Plate 3) at 0.1, 0.2 and 0.3 per cent concentrations. Among the four combi products, carbendazim (12\%) + mancozeb (63\%) WP was found highly effective with 100 per cent inhibition at all the three concentrations tested, followed by tricyclazole $(18 \%)+$ mancozeb $(62 \%) \mathrm{WP}$ with 95.92, 100 and 100 per cent and hexaconazole $(4 \%)+$ zineb $(68 \%) \mathrm{WP}$ with $92.22,100$ and 100 per cent at $0.1,0.2$ and 0.3 per cent concentrations respectively, as compare to control.

However, azoxystrobin $(11 \%)+$ tebuconazole (18.3\%) SC was found comparatively less effective with $79.62,86.47$ and 96.66 per cent inhibition at $0.1,0.2$ and 0.3 per cent concentrations, respectively. Irrespective of fungicidal concentrations, carbendazim (12\%) + mancozeb (63\%) WP resulted cent per cent inhibition and found to be best and significantly superior over other fungicides tested.

\section{In vitro evaluation of bioagents by using dual culture technique}

The antagonistic actions of selected six biocontrol agents against $P$. grisea were carried out through dual culture technique. Based on the observation of radial growth of the bioagent and fungus, per cent inhibition was calculated. The results are presented in Table 4 and Plate 4. Among the fungal bioagents tested, T. harzianum (Tri 5) was found more effective and statistically significant over other bio-control agents in inhibiting the mycelial growth of 77.03 per cent followed by $T$. viride (Tri 4) with 66.66 per cent. Among the bacterial bioagents, $P$. fluoresces (RP-46) was very effective with mycelial inhibition of 67.77 per cent. However, the least mycelial inhibition was recorded in B. subtilis (BS-16) with 38.51 per cent. The rest of the biocontrol agents were found least effective and found in the range of 41.84 to 44.07 per cent inhibition of pathogen.

Among the different fungicides evaluated, systemic and combi fungicides were found effective except azoxystrobin in inhibiting the growth of fungus. Among systemic fungicides, tricyclazole was found effective in inhibiting the fungal growth of $P$. grisea with cent per cent inhibition at all concentration tested $(0.05,0.1$ and $0.2 \%)$ followed by carbendazim (Table 1). This may be due to inhibition of sterol bio synthesis. Similar results were reported by Joshi and Gohel (2015). Among the contact fungicides tested, mancozeb was found effective in inhibiting the growth of $P$. grisea at all concentrations tested $(0.1,0.2$ and $0.3 \%)$ followed by copper oxychloride with mycelial inhibition of 83.58 per cent (Table 2). Similar results were reported by Roopadevi and Patil (2017). Among four combi fungicides tested, carbendazim $(12 \%)+$ mancozeb (63\%) WP was found highly effective with cent per cent inhibition at all three concentrations tested (Table 3). Similar results were reported by Roopadevi and Patil (2017). Among the bioagents tested, $T$. harzianum (Tri 5) and $P$. fluorescens (RP-46) were found effective with 77.03 and 67.77 per cent inhibition respectively (Table 4). The inhibitory effect of these bioagents was probably due to competition or antibiosis. Similar results were reported by Kishan Lal et al., (2015).

\section{References}

Anonymous, 2017. Ministry of Agriculture and Farmers Welfare, Govt. of India. 
Dennis, C. and Webster, J., 1971, Antagonistic properties of species groups of Trichoderma II. Production of Volatile antibiotics. Trans Br. Mycol. Soc., 57: 41-48.

Joshi, H. D. and Gohel, N. M., 2015, Management of blast [Pyricularia grisea (Cooke) Sacc.] disease of pearl millet through fungicides. The Bioscan, 10(4): 1855-1558.

Kishan Lal., Ramesh Singh Yadav. and Satish Chand., 2015., In vitro management of rice blast caused by $P$. oryzae with Pseudomonas Fluorescens \& Fungicides, The Ecoscan, 9(3 \& 4): 1001-1006.

Mehta, P. R., Singh, B. and Mathur, S. C., 1953, A new leaf spot disease of bajra (Pennisetum typhoides Staph and Hubbard) caused by a species of Pyricularia. Indian Phytopathol, 5: 140143.
Roopadevi and Patil, P. V., 2017, In vitro bioassay of fungicides, bioagents, botanicals and it's against Pyricularia grisea (Cooke) Sacc. Incitant of pearl millet blast, Int. J. Pure App. Biosci. 5(5): 1457-1463.

Thakur, R. P., Sharma, R. and Rao, V. P., 2011, Screening Techniques for Pearl Millet Diseases. Information Bulletin No. 89. Patancheru 502324, Andhra Pradesh, India: International Crops Research Institute for the Semi-Arid Tropics. p.15.

Thakur, R. P., Sharma, R., Rai, K. N., Gupta, S. K. and Rao, V. P., 2009, Screening techniques and resistance sources for foliar blast in pearl millet. J. SAT Agri. Res., 7: 1-5.

Vincent, J. H., 1947, Distortion of fungi hyphae in the presence of certain inhibitors. Nature, 159: 850.

\section{How to cite this article:}

Mahesh, M., L. Malatesha and Venkataravana, P. 2019. In vitro Evaluation of Fungicides and Bioagents for the Management of Pearl Millet Blast Caused by Pyricularia grisea (Cooke) Sacc. Int.J.Curr.Microbiol.App.Sci. 8(06): 1422-1429. doi: https://doi.org/10.20546/ijcmas.2019.806.172 